\title{
ANALISIS TERHADAP DETERMINAN SPREAD SUKU BUNGA BANK UMUM DI INDONESIA PERIODE 2009-2013.
}

\author{
Oleh: \\ Linda Ratna Sari \\ Dinas Pendapatan Daerah Kabupaten Malang \\ E-mail : lindaratnasari937@yahoo.com
}

\begin{abstract}
This study was aimed to know the effect of dependent variable, spread of public bank rate in Indonesia period 2009-2013.Multiple linear regressions with model of least quadrat estimation were used as analysis tool. In the model equation, spread rate of interest (interest rates on loans and interest rates on savings) was a dependent variable, and then the independent variable was BI rate, ROA, NPL, and SIBOR.The result of this current study showed that BI rate and ROA had a negative effect and significant on spread rate of interest, whereas NPL and SIBOR had a positive effect and significant on spread rate of interest. Simultaneously, BI rate, ROA, NPL, SIBOR influence the spread rate of interest. Meanwhile, trial on classic assumption showed that all regressions had pulled through from classic assumption (autocorrelation, heterocedasticity, multicollinearity). Coefficient determination (R2) of regression interest rate spread was 0,708181 or $70.82 \%$. it showed that independent variable consist of BI rate, ROA, NPL, and SIBOR clarified the changing of dependent variable interest rate spread as big as $70.82 \%$, whereas the remaining $0.29 \%$ was clarified by other variable that is not included in estimation model.
\end{abstract}

Keywords : BI rate, Return on Asset, Non Performing Loan, Singapore interbank offering rate.

\begin{abstract}
ABSTRAK
Tujuan penelitian ini adalah untuk mengetahui pengaruh yang ditujukan oleh variabel dependent yaitu spread suku bunga terhadap bank umum di Indonesia periode 2009-2013. Alat analisis yang digunakan adalah regresi linier berganda dengan model estimasi kuadrat terkecil. Dalam persamaan model, spread suku bunga (suku bunga pinjaman dengan suku bunga tabungan) adalah variabel terikat dan BI Rate, ROA, NPL dan SIBOR adalah variabel bebas. Hasil analisis menunjukkan bahwa variabel BI Rate dan ROA berpengaruh negative dan signifikan terhadap spread suku bunga sedangkan NPL dan SIBOR berpengaruh positif dan signifikan terhadap spread suku bunga. Sedangkan secara silmultan variabel BI Rate, ROA, NPL dan SIBOR berpengaruh terhadap spread suku bunga. Sedangkan pengujian terhadap asumsi klasik menunjukkan bahwa dari keempat regresi yang telah dilakukan sudah lolos dari asumsi klasik (Autokorelasi, Heterokedastisitas dan Multikolinearitas). Determinasi Koefisien $\left(\mathrm{R}^{2}\right)$ dari Regresi spread suku bunga sebesar 0,708181 atau $70.82 \%$ hal ini menunjukkan bahwa variabel independent yang terdiri dar BI Rate, ROA, NPL dan SIBOR dalam menjelaskan perubahan variabel dependent spread suku bunga
\end{abstract}


sebesar $70.82 \%$ sedangkan sisanya sebesar $0.29 \%$ dijelaskan oleh variabel lain yang tidak dimasukkan dalam model estimasi.

Kata Kunci : BI Rate, Return On Asset, Non Performing Loan, Singapore interbank offering rate

\section{PENDAHULUAN}

Perbankan merupakan sistem keuangan terutama pada sektor pertumbuhan ekonomi, mengingat pengertian Bank menurut UndangUndang Perbankan Nomor 10 Tahun 1998 merupakan badan usaha yang menghimpun dana masyarakat dalam bentuk simpanan dan menyalurkan kepada masyarakat dalam bentuk kredit atau bentuk lainnya dalam rangka meningkatkan taraf hidup rakyat. Oleh karena itu, sistem keuangan merupakan sumber yang paling utama dari pembiayaan keputusan ekonomi yang berkaitan dengan investasi dan komsumsi, yang bertujuan untuk meningkatkan pertumbuhan produktivitas. Akibatnya, harga pembiayaan melalui pinjaman bank (suku bunga kredit) dan efisiensi perbankan (diukur dengan spread suku bunga) sangat penting untuk alokasi potensi keuangan tambahan dalam perekonomian sehingga dapat meningkatkan pertumbuhan ekonomi.
Melalui intermediasi keuangan adalah proses pembelian dana dari unit surplus (penabung) untuk selanjutnya kembali kepada unit deficit (peminjam), Keberadaan Dana Pihak Ketiga ini mempunyai peran yang penting dalam meningkatkan pendapatan bank, karena dari Dana Pihak Ketiga kemudian disalurkan menjadi kredit. Kredit yang disalurkan bank akan mendapatkan tingkat pengembalian berupa hasil bunga. Selanjutnya besar kecilnya hasil bunga akan sangat mempengaruhi besar kecilnya profitabilitas. Oleh karena itu optimalisasi Dana Pihak Ketiga menjadi sangat penting di dalam meningkatkan profitabilitas.

Pada umumnya kesehatan bank adalah bank yang dapat melaksanakan fungsi-fungsinya dengan baik seperti kepercayaan pada masyarakat dan menjalankan fungsi intermediasi untuk membantu kelancaran lalu lintas pembayaran serta dapat digunakan oleh pemerintah untuk melaksanakan 
kebijakan moneter. Agar dapat menjalakan fungsinya dengan baik, maka bank harus mempunyai modal yang cukup, seperti menjaga kualitas aset dengan baik, dikelola dengan baik dan di operasikan dengan prinsip kehati-hatian. kesehatan bank merupakan kemampuan suatu bank untuk melakukan kegiatan operasional perbankan secara normal dan mampu memenuhi semua kewajibannya dengan baik dengan cara-cara yang sesuai dengan peraturan yang berlaku.

$$
\text { Pada tahun 2008-2009 }
$$

terjadinya krisis keuangan global, pada tahun 2009 BI memberikan himbauan, para banker sepakat untuk menjaga tingkat suku bunga dana pihak ke 3 di tingkatan 6-7\% atau $0.5 \%$ di atas BI rate. Apabila terjadi persaingan tidak sehat dalam pasar dana pihak ketiga, terutama dalam nasabah besar. Dalam hal ini bankir tidak melakukan penyesuaian terhadap suku bunga kredit, sehingga spread suku bunga kredit dan suku bunga dana pihak ketiga makin besar. (Taufik, 2011).

Tingginya indikator inefisiensi memberikan berkah bagi perbankan Pada tahun 2010 sebesar Rp. 57,3
Trilliun atau tumbuh sebesar $26.8 \%$ dari tahun 2009. dalam faktor pertumbuhan kredit, spread suku bunga tinggi diduga mempengaruhi pencapaian laba perbankan. Para bankir menyatakan bahwa indikator inefisiensi tidak bisa di samakan dengan dengan negara tetangga karena tingkat inflasi tinggi maka suku bunga kredit akan tinggi. Bank Indonesia telah berupaya untuk menekan dan menurunkan suku bunga kredit ke tingkat yang kebih wajar.

Tingkat suku bunga diartikan sebagai indikator dalam mempengaruhi keputusan masyarakat dalam menabung uang untuk jangka pajang, juga mempengaruhi dalam mengambil keputusan di dunia usaha dalam melakukan pinjaman untuk berbagai kepentingan investasi. Tingginya spread suku bunga dapat mengakibatkan peningkatan biaya modal yang lebih tinggi bagi peminjam sehingga berdampak pada berkurangnya investasi karena resikonya yang tinggi. spread suku bunga yang tinggi dapat mempengaruhi bisnis atau usaha ekonomi, terutama bagi usaha kecil 
yang dimana bank tidak membantu dalam memberikan modal karena rentang akan terjadinya kredit macet sehingga tidak terjadi pemerataan dalam peminjaman modal.

Seperti yang diungkapkan oleh Nasution (2012), tingginya spread suku bunga akan membantu Indonesia sulit bersaing dalam Masyarakat Ekonomi Asean (MEA) pada tahun 2020 mendatang, hal ini karena spread suku bunga yang tinggi membuat kredit lebih mahal dan mengakibatkan penurunan kredit di masyarakat karena tingginya tingkat bunga. Maka menunjukkan bahwa tingginya spread suku bunga akan menghambat pertumbuhan suatu negara.

Spread suku bunga di Indonesia apabila di bandingkan dengan negara tetangga seperti Malaysia, Singapura, Brunei, Philipina dan Thailand termasuk paling tinggi. Sebagai berikut data spread suku bunga.

Tabel 1. Spread Suku Bunga Bank di Indonesia dan Negara Tetangga

\begin{tabular}{ccccccc}
\hline Tahun & Indonesia & Brunei & Malaysia & Singapura & Philipina & Thailand \\
\hline $\mathbf{2 0 0 7}$ & $5.9 \%$ & $4.3 \%$ & $3.2 \%$ & $4.8 \%$ & $5.0 \%$ & $4.2 \%$ \\
\hline $\mathbf{2 0 0 8}$ & $5.1 \%$ & $4.6 \%$ & $3.0 \%$ & $5.0 \%$ & $4.3 \%$ & $4.6 \%$ \\
\hline $\mathbf{2 0 0 9}$ & $5.2 \%$ & $4.8 \%$ & $3.0 \%$ & $5.1 \%$ & $5.8 \%$ & $4.9 \%$ \\
\hline $\mathbf{2 0 1 0}$ & $6.2 \%$ & $5.0 \%$ & $2.5 \%$ & $5.2 \%$ & $4.5 \%$ & $4.9 \%$ \\
\hline $\mathbf{2 0 1 1}$ & $5.5 \%$ & $5.1 \%$ & $2.0 \%$ & $5.2 \%$ & $3.3 \%$ & $4.6 \%$ \\
\hline $\mathbf{2 0 1 2}$ & $5.8 \%$ & $5.3 \%$ & $1.8 \%$ & $5.2 \%$ & $2.5 \%$ & $4.3 \%$ \\
\hline
\end{tabular}

Sumber : Wordl bank (data diolah) pada tahun 2007-2012

Berdasarkan data di atas dapat disimpulkan bahwa spread suku bunga di Indonesia merupakan yang tertinggi di bandingkan dengan negara tetangga seperti Brunei, Malaysia, Singapura, Philipina dan Thailand mulai dari tahun 2007 sampai 2012. Hal ini membuktikan bahwa kurangnya efisien terhadap sistem perbankan di negara tetangga lebih baik dari pada Indonesia. Spread suku bunga di Indonesia telah mengalami fluktuasi dalam 6 tahun terakhir, hal ini membuktikan bahwa kurangnya efisiensi sistem perbankan dan sistem keuangan Indonesia, berbeda dengan negara tetangga tetangga seperti Brunei, Malaysia, Singapura, penurunan terus-menerus 
menandai efisiensi sistem perbankan di negara tersebut stabil.

Penurunan tingkat suku bunga SIBOR yang di mulai pada tahun 2008 tidak dapat di ikuti oleh penurunan tingkat suku bunga di Indonesia. Penurunan tingkat suku bunga di negara singapura terkait dengan krisis ekonomi global yang menyababkan pertumbuhan ekonomi di sejumlah negara dunia mengalami perlambatan termasuk di kawasan asia pasifik dimana singapura termasuk salah satu negara pusat beroperasinya keuangan dunia sehingga memicu kebijakan untuk menurunkan suku bunga pada negara tersebut dengan tujuan meningkatkan pertumbuhan ekonomi.

Kebijakan penurunan tingkat suku bunga di berbagai negara Asia termasuk singapura, tidak diikuti oleh kebijakan yang sama untuk negara Indonesia. Dengan adanya perbedaan kondisi makroekonomi antar kedua negara dan seiring dengan adanya situasi gejolak inflasi pada tahun 2008 dan sering dengan melemahnya nilai tukar rupiah terhadap dollar amerika pada tahun 2009, sehingga berdampak pada pada kenaikan suku bunga perbankan guna meredam laju inflasi pada tahun 2008. Dengan adanya kenaikan tingkat suku bunga deposito pada perbankan di Indonesia, diharapkan dapat berdampak pada aliran modal masuk, sehingg akan memicu penguatan mata uang rupiah lebih lanjut, kenaikan tingkat suku bunga depositi sebagai salah satu komponen biaya dana bagi perbankan selanjutnya akan direspon oleh kenaikan tingkat suku bunga pinjaman pada perbankan di Indonesia (Waljianah,2013).

Tingkat suku bunga acuan adalah BI Rate dalam pergerakan suku bunga di pasar keuangan. Peningkatan maupuan penurunan BI Rate diharapakn akan diikuti oleh peningkatan / pinjaman. Kebijakan BI Rate sebagai tingkat suku bunga acuan dalam mempengaruhi tingkat suku bunga pinjaman tidak berjalan secara responsive. Kebijakan menaikkan BI Rate pada tahun 2005 akibat adanya tekanan inflasi pada perode tersebut. Pada tahun 2007 penurunan BI Rate cenderung stabil sejak tahun 2009 hingga tahun 2011 kurang direspon oleh pergerakan tingkat suku bunga pinjaman, tingkat 
suku bunga pinjaman cenderung kurang signifikan.

Negara Indonesia dengan kondisi perekonomian yang terbuka yang juga melakukan hubungan internasional, seperti SIBOR (suku bunga luar negeri) yang merupakan factor - faktor mempengaruhi pergerakan suku bunga di Indonesia kebijakan BI Rate, factor - faktor yang berasal dari makro perekonomian Indonesia dan luar negeri tetap berpengaruh pada penentu tingkat suku bunga pinjaman di Indonesia. variabel lainnya yang berpengaruh yaitu ROA dimana Tingkat prifitabilitas dapat diukur menggunakan dan NPL (non performing loan) berpengaruh terhadap spread suku bunga yang dimana pinjaman yang dengan lancar dapat mengakibatkan manager bank menambah biaya operasional untuk mengahadapi resiko dari adanya pinjaman tidak lancar tersebut.

\section{METODE PENELITIAN}

Objek penelitian yang dipilih oleh peneliti adalah langkah dan prosedur yang akan dilakukan dalam mengumpulkan data dan atau informasi empiris guna memecahkan permasalahan dan menguji hipotesis penelitian. Daerah penelitian ini dilakukan di Indonesia dengan mengambil data mulai dari tahun 2009 sampai dengan tahun 2013.

Penelitian ini bersifat deskriptif kuantitatif, yaitu penelitian yang sifatnya memberikan gambaran secara sistimatis subyek penelitian yang telah dipilih kemudian menganalisis serta menyimpulkan antara variabel bebas, yang terdiri dari BI Rate, ROA, NPL dan SIBOR terhadap variabel terikatnya yaitu spread suku bunga di bank umum indonesia.

Data yang dikumpulkan meliputi:

1) Data BI Rate periode 2009-2013

2) Data Return On Asset (ROA) periode 2009-2013

3) Data Non Performing Loan (NPL) periode 2009-2013

4) Data Singapore Interbank Offering Rate (SIBOR) periode 2009-2013

Metode estimasi yang digunakan adalah metode kuadrat terkecil biasa (Ordinary Least Square). Metode Kuadrat Terkecil Biasa adalah suatu metode estimasi yang dilakukan dengan cara memperkecil kesalahan penaksiran 
dengan cara menderivasi jumlah kuadrat kesalahan terhadap nilai penaksir parameter hingga nol.

Untuk mendapat hasil regresi antara variabel bebas (BI rate, ROA, NPL dan Sibor) dan variabel terikat (Spread Suku Bunga) maka digunakan data sekunder yang bersumber dari Bank Indonesia yang dicatat mulai dari tahun 2009 sampai dengan tahun 2013 dalam bentuk persen dan diolah dengan menggunakan program Eviews 4.

Model estimasi persamaannya adalah sebagai berikut :

$$
\begin{gathered}
Y_{1}=\alpha+\beta_{1} X_{1}+\beta_{2} X_{2}+\beta_{3} X_{3}+\beta_{4} \\
X_{4}+\text { ei }
\end{gathered}
$$

Dimana :

$$
\begin{array}{ll}
\mathrm{Y}_{1} & : \text { Spread Suku Bunga } \\
\alpha & : \text { intercept } \\
\beta_{1}, \beta_{2}, & \beta_{3}, \beta_{4: \text { Koefisien Regresi }} \\
\mathrm{X} 1 \quad \text { : BI Rate }(\%) \\
\mathrm{X} 2 \quad: \operatorname{ROA}(\%) \\
\mathrm{X} 3 \quad: \operatorname{NPL}(\%) \\
\mathrm{X} 4 \quad: \text { SIBOR }(\%) \\
\text { ei } \quad: \text { term of error }
\end{array}
$$$$
\text { Untuk menganalisis dan }
$$
menguji data dalam penelitian, peneliti menggunakan uji statistik dan uji ekonometrika. Uji statistik digunakan Hipotesis, antara lain uji “t”, uji” F" dan Determinasi Koefisien. Sedangkan uji ekonometirka digunakan untuk menguji penyimpangan asumsi klasik antara lain uji Heterokedastisitas, Uji Multikolinearitas dan uji Autokorelasi.

\section{PEMBAHASAN}

Pada pembahasan ini akan membahas mengenai perkembangan variabel independent serta variabel dependent dan juga faktor-faktor yang mempengaruhinya. Pada penelitian ini, variabel dependent terdiri dari BI Rate, ROA, NPL dan SIBOR. Sedangkan variabel independent spread suku bunga.

\section{Spread Suku Bunga}

Pada penelitian ini, variabel dependent yang digunakan adalah spread suku bunga. Pada dasarnya spread suku bunga merupakan selisih antara suku bunga pinjaman dengan suku bunga tabungan, spread suku bunga pinjaman dikurangi suku bunga tabungan. 
Gambar 1. Perkembangan Spread Suku Bunga Tahun 2013

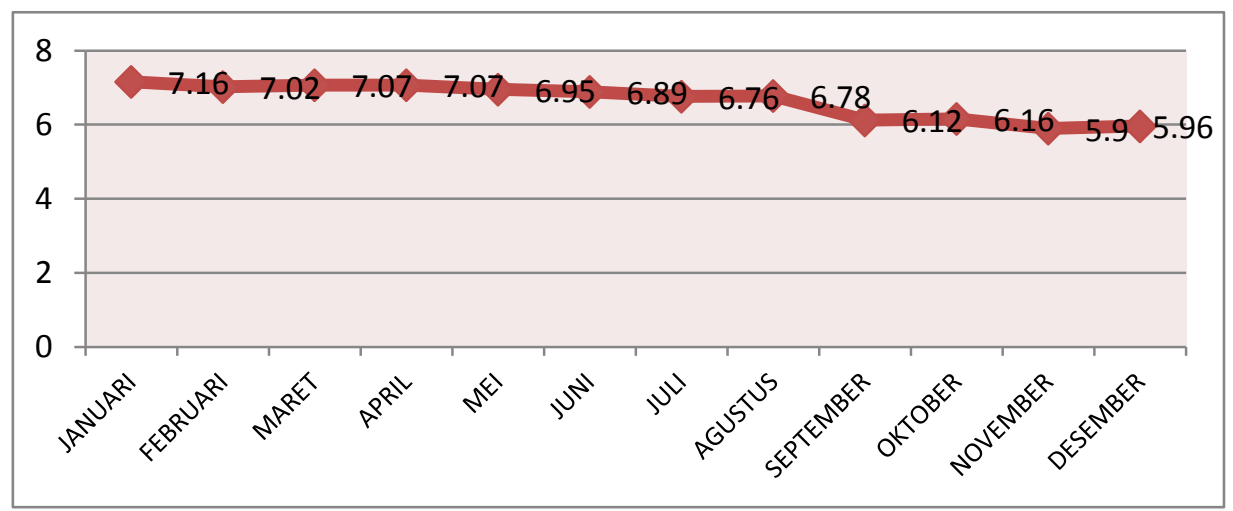

Sumber : Bank Indonesia di olah tahun 2015

Dapat dilihat pada grafik diatas

perkembangan Spread Suku Bunga pada tahun 2013, di bulan januari sebesar 7.16 pada bulan februari mengalami penurunan sebesar 7.02 kemudian pada bulan maret dan april mengalami peningkatan yang sama sebesar 7.07 dan 7.07 pada bulan mei mengalami penurunan sebesar 6.95 pada bulan juni dan juli mengalami penurunan sebesar 6.89 dan 6.76 pada bulan agustus mengalami peningkatan sebesar 6.78 pada bulan
September mengalami penurunan sebesar 6.12 kemudian pada bulan oktober mengalami peningkatan sebesar 6.16 pada bulan November mengalami penurunan sebesar 5.90 kemudian mengalami peningkatan pada bulan desember sebesar 5.96.

\section{BI Rate}

BI Rate adalah suku bunga kebijakan yang mencerminkan sikap atau stance kebijakan moneter yang ditetapkan oleh bank Indonesia dan diumumkan kepada publik

Gambar 2. Perkembangan BI Rate Tahun 2013

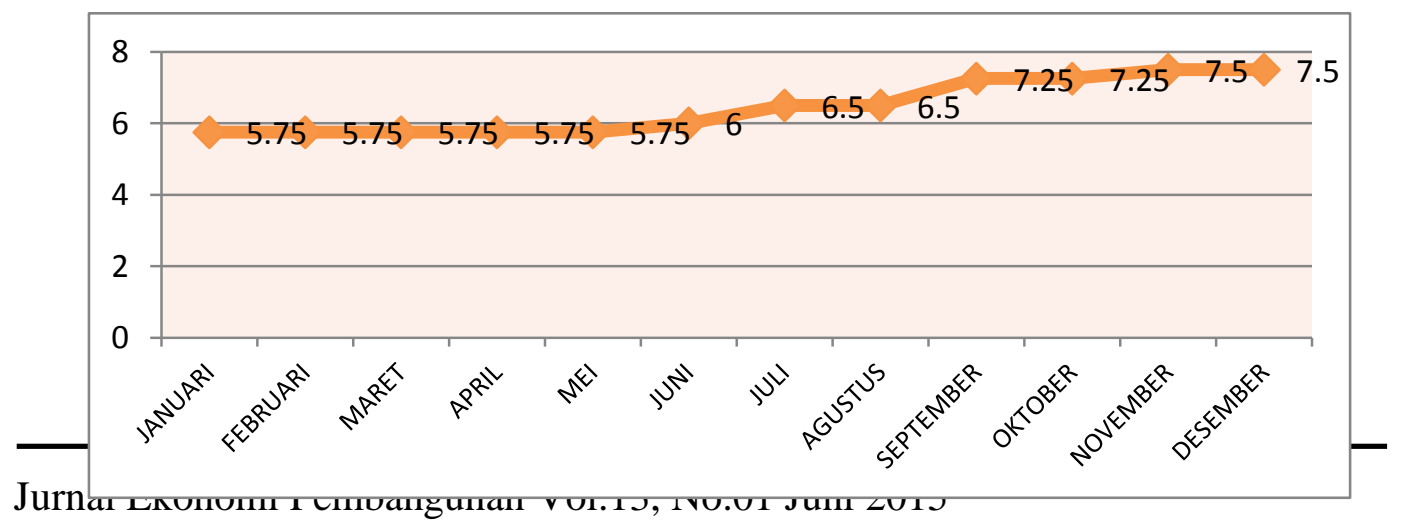




\section{Sumber : Data Bank Indonesia di Olah Tahun 2015}

Dapat dilihat pada grafik diatas perkembangan $\mathrm{BI}$ rate pada tahun 2012, di bulan januari sebesar 5.75 pada bulan februari, maret, april, dan mei mengalami peningkatan yang sama sebesar 5.75. kemudian pada bulan juni, juli, agustus, September, oktober, November dan desember mengalami peningkatan yang sebesar 6.00, 6.50, dan 7.50.

\section{ROA Return On Asset}

Return on asset (ROA) adalah aktiva untuk mengahsilkan laba bersih atau rasio ini digunakan untuk mengukur kemampuan menajemen bank dalam memperolah keuntungan laba secara keseluruhan.

\section{Gambar 4. Perkembangan ROA tahun 2013}

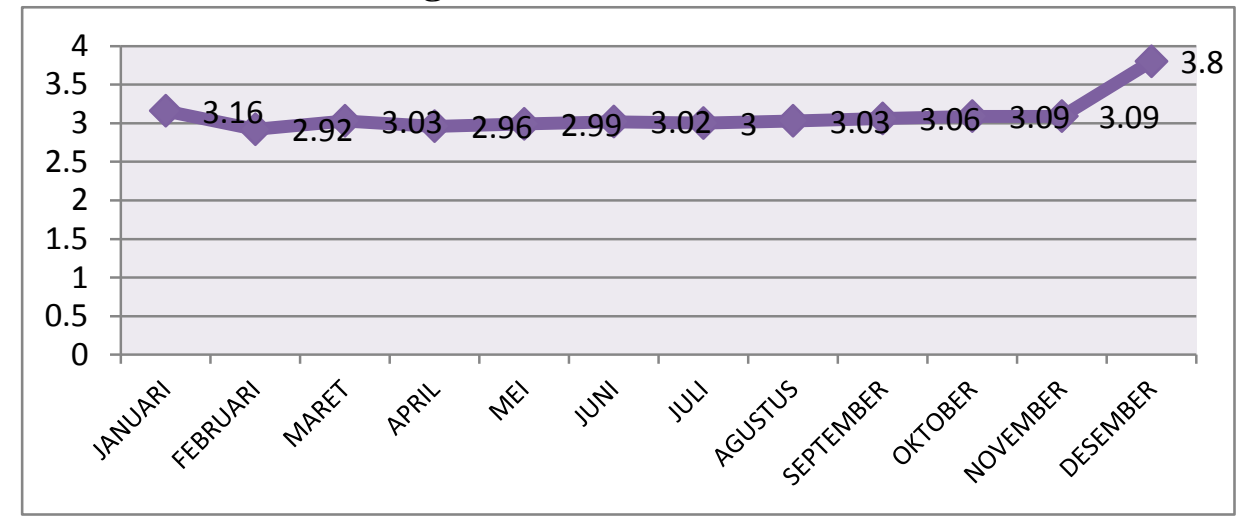

Sumber : Bank Indonesia di Olah Tahun 2015

Dapat dilihat pada garafik diatas juli mengalami penurunan sebesar perkembangan ROA pada tahun 2013, 3.00 kemudian pada bulan agustus, di bulan januari sebesar 3.16 pada September, oktober, November dan bulan februari mengalami penurunan sebesar 2.92 kemudian pada bulan maret pengalami peningkatan sebesar 3.03 pada bulan april mengalami penurunan sebesar 2.96 pada bulan mei pengalami peningkatan sebesar 2.99 pada bulan juni mengalami peningkatan sebesar 3.02 pada bulan desember mengalami peningkatan secara berturut-turut sebesar 3.03, 3.06, 3.09, 3.09 dan 3.80.

\section{Non Peforrming Loan (NPL)}

Non Performing Loan (NPL) atau kredit bermasalah merupakan salah satu indikator kunci untuk menilai kinerja fungsi bank. Salah satu fungsi 
bank adalah sebagai lembaga dengan pihak yang membutuhkan intermediary atau penghubung antara dana.

pihak yang memiliki kelebihan dana

\section{Gambar 5. Perkembangan NPL Tahun 2013}

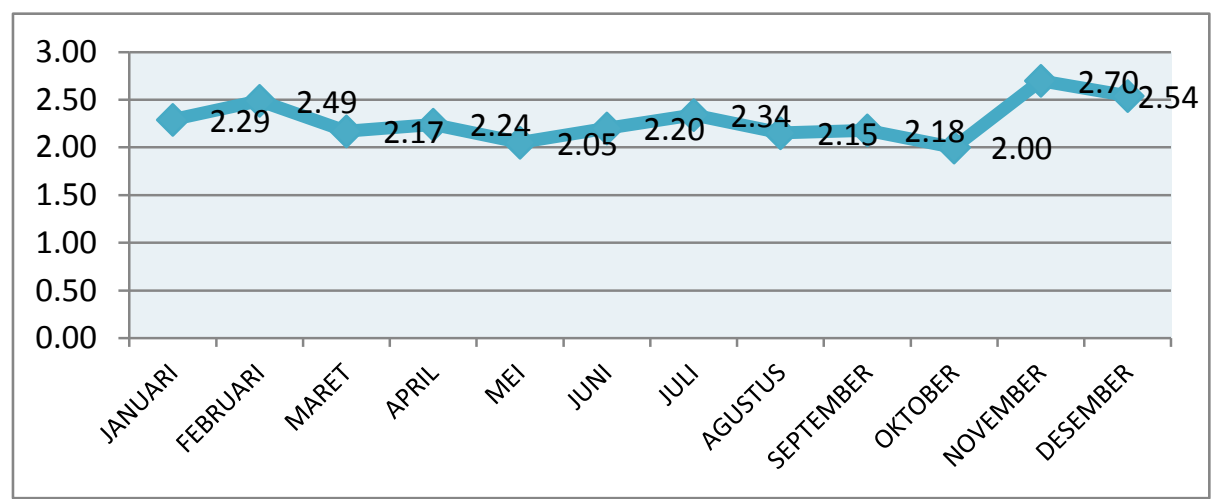

Sumber : Bank Indonesia di olah tahun 2015

Dapat dilihat pada grafik diatas perkembangan

NPL (non performance loan) pada tahun 2012, di bulan januari sebesar 2.29 pada bulan februari mengalami peningkatan sebesar 2.49 pada bulan maret mengalai penurunan sebesar 2.17 pada bulan april mengalami peningkatan sebesar 2.24 pada bulan mei mengalami penurunan sebesar 2.05 kemudian pada bulan juni dan juli mengalami peningkatan sebesar 2.20 dan 2.34 pada bulan agustus mengalami penurunan sebesar 2.15 pada bulan September, oktober dan November mengalami peningkatan sebesar 2.18, 2.00 dan 2.70 pada bulan desember mengalami penurunan sebesar 2.54.

\section{Singapore Interbank Offering Rate (SIBOR)}

Merupakan valuta asing yang aktif diperdagangkan di seluruh dunia, termasuk di Indonesia sendiri. Berdasarkan teori paritas, dengan adanya kondisi menurunnya nilai mata uang rupiah terhadap dollar (depresiasi), maka tingkat suku bunga nominal di dalam negeri harus lebih tinggi dari pada tingkat suku bunga nominal di luar negeri sebagai kompensasi atas menurunnya nilai asset (deposito) dalam bentuk rupiah. 


\section{Gambar 6 Perkembangan SIBOR Tahun 2013}

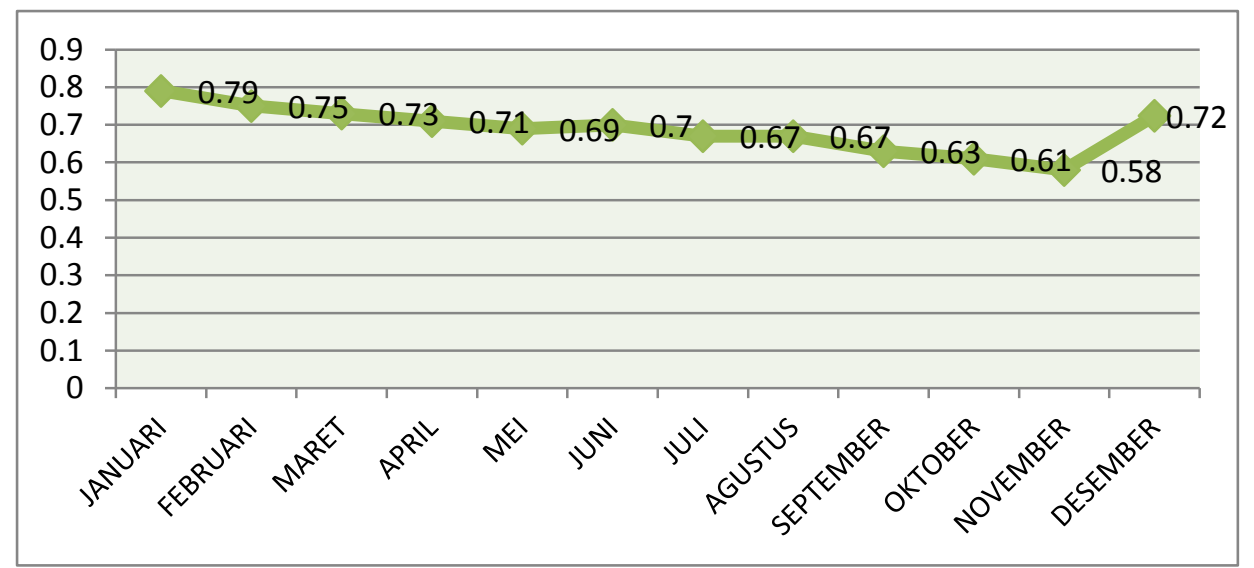

Sumber : Bank Indonesia di Olah Tahun 2015

Dapat dilihat pada grafik diatas perkembangan SIBOR (Singapore interbank offering rate) pada tahun 2013, di bulan januari sebesar 0.79 pada bulan februari, maret, april dan mei mengalami penurunan secara berturut-turut sebesar $0.75,0.73$, 0.71 dan 0.69 kemudian pada bulan juni mengalami peningkatan sebesar 0.70 pada bulan juli, agustus, September, oktober dan November mengalami penurunan secara berturut-turut sebesar $0.67,0.67$, 0.63, 0.61 dan 0.58 pada bulan desember mengalami peningkatan sebesar 0.72 .

\section{HASIL ANALISIS DATA}

Untuk mendapat hasil regresi anatara variabel bebas (BI rate, ROA, NPL dan SIBOR) dan variabel terikat (Spread Suku Bunga) maka digunakan data sekunder yang bersumber dari Bank Indonesia yang dicatat mulai dari tahun 2009 sampai dengan tahun 2013 dalam bentuk persen dan diolah dengan menggunakan program Eviews 4.

Berdasarkan data yang diperoleh dari hasil penelitiannya yaitu data yang telah diolah kedalam model melalui program Eviews 4.1. hasil estimasi tersebut dalam table berikut ini : 
Tabel 4.3 : Hasil Estimasi Regresi Spread Suku Bunga

Dependent Variable: $Y$

Method: Least Squares

Date: 03/19/15 Time: 21:54

Sample: 2009:01 2013:12

Included observations: 60

\begin{tabular}{crlrr}
\hline \hline \multicolumn{1}{c}{ Variable } & Coefficient & Std. Error & t-Statistic & Prob. \\
\hline \hline C & 9.812189 & 0.980784 & 10.00444 & 0.0000 \\
X1 & -0.290086 & 0.077336 & -3.750980 & 0.0004 \\
X2 & -1.077079 & 0.237923 & -4.527006 & 0.0000 \\
X3 & 0.610417 & 0.095923 & 6.363608 & 0.0000 \\
X4 & 1.127629 & 0.261801 & 4.307206 & 0.0001 \\
\hline \hline R-squared & 0.708181 & Mean dependent var & 7.421333 \\
Adjusted R-squared & 0.686958 & S.D. dependent var & 0.606332 \\
S.E. of regression & 0.339244 & Akaike info criterion & 0.755460 \\
Sum squared resid & 6.329754 & Schwarz criterion & 0.929989 \\
Log likelihood & -17.66381 & F-statistic & 33.36827 \\
Durbin-Watson stat & 1.754861 & Prob(F-statistic) & 0.000000 \\
\hline \hline
\end{tabular}

Sumber : Eviews 4

\section{Persamaan Regresi}

$Y=9.812189-0.290086^{\star} X 1-1.077079^{\star} X 2+0.610417^{\star} X 3+1.127629^{\star} X 4$

Dimana :

$\alpha: 9.812189$ adalah konstanta,

yang berarti besarnya jumlah

Spread suku bunga ( $\mathrm{Y}$ ) sebesar

9.812189 pada saat BI Rate (X1),

ROA (X2), NPL (X3) dan

SIBOR (X4) adalah nol/konstan.

$\beta_{1:} \quad-0.290086$ adalah besarnya

koefisien regresi untuk BI Rate

(X1) sebesar - 0.290086, hal ini menunjukkan pengaruh negatif antara BI Rate (X1) terhadap spread suku bunga sebesar $0.290086 \%$. Kondisi ini menunjukkan setiap kenaikan BI Rate sebesar $1 \%$ maka spread suku bunga akan turun sebesar $0.290086 \%$ dengan asumsi variabel yang lain tetap. 
$\beta_{2:}-1.077079$ adalah besarnya koefisien regresi untuk ROA return on aset (X2) sebesar 1.077079, hal ini menunjukkan pengaruh negatif BI Rate (X2) terhadap spread suku bunga sebesar - $1.077079 \%$. Kondisi ini menunjukkan setiap kenaikan ROA return on asset sebesar $1 \%$ maka spread suku bunga akan turun sebesar - $1.077079 \%$ dengan asumsi variabel yang lain tetap.

$\beta_{3:} 0.610417$ adalah besarnya koefisien regresi untuk NPL non Performance loan (X3) sebesar 0.610417, hal ini menunjukkan pengaruh NPL non performance loan (X3) terhadap spread suku bunga sebesar $0.610417 \%$. Kondisi ini menunjukkan setiap kenaikan sebesar NPL non performance loan 1\% maka spread suku bunga akan turun sebesar $0.610417 \%$ dengan asumsi variabel yang lain tetap.

$\beta_{4:} \quad 1.127629$ adalah besarnya koefisien regresi untuk SIBOR Singapore Interbank Offering Rate (X4) sebesar 1.127629, hal ini menunjukkan pengaruh positif SIBOR Singapore Interbank
Offering Rate (X4) terhadap spread suku bunga sebesar $1.127629 \%$. Kondisi ini menunjukkan setiap kenaikan SIBOR sebesar 1\% maka spread suku bunga akan naik sebesar $1.127629 \%$ dengan asumsi variabel yang lain tetap.

\section{Uji Kesesuaian Hipotesis}

Uji kesesuaian hipotesis ini dilakukan untuk mengetahui kebenaran dari hipotesis tentang pengaruh variabel independent terhadap variabel dependent. Uji kesesuaian hipotesis ini terdiri dari uji t, uji $\mathrm{F}$ dan koefisien determinasi.

\section{1) Uji t}

Tujuan dilakukannya uji $\mathrm{t}$ adalah untuk mengetahui pengaruh variabel independent terhadap variabel dependent secara individu/parsial. Variabel independent yang akan diuji antara lain terdiri dari :

\section{a) BI Rate (X1)}

Dari hasil regresi diatas diketahui t-hitung : $\quad-3,750980$ sedangkan signifikan yang digunakan adalah $\alpha: 5 \%$ df sehingga untuk pengujian $\mathrm{t}$ dengan 2 arah, signifikan $0,025 \%$ dan df: n-k-1(604-1) maka nilai t-tabel yang didapatkan $0,025 \%(55): \pm 2,00404$. 
Secara parsial BI Rate mempunyai pengaruh negative terhadap spread suku bunga yang dihimpun oleh Bank Umum Di Indonesia.

\section{b) Return On Asset (ROA)}

Dari hasil regresi diatas diketahui t-hitung : $\quad-4.527006$ sedangkan signifikan yang digunakan adalah $\alpha: 5 \%$ df sehingga untuk pengujian dengan 2 arah dengan signifikan $0.025 \%$ data $\mathrm{df}$ : n-k-1(60-4-1) maka nilai t-tabel yang didapatkan $0,025 \%(55): \pm 2,00404$. Secara parsial ROA mepunyai pengaruh negatif terhadap spread suku bunga yang dihimpun oleh Bank Umum Di Indonesia.

\section{c) Non Performing Loan (NPL)}

Untuk mengetahui pengaruh NPL (non performing loan) terhadap spread suku bunga yang di himpun oleh bank umum di Indonesia akan dilakukan uji hipotesis secara individu.

Dari hasil regresi diatas diketahui $\mathrm{t}$ - hitung : 6.363608 sedangkan signifikan yang digunakan adalah $\alpha: 5 \%$ df sehingga untuk pengujian dengan 2 arah dengan signifikan $0.025 \%$ data df : n-k-1(60-4-1) maka nilai t-tabel yang didapatkan $0,025 \%(55): \pm 2,00404$.
Secara parsial NPL mepunyai pengaruh positif terhadap spread suku bunga yang dihimpun oleh Bank Umum Di Indonesia.

\section{d) Singapore Interbank Offering Rate (SIBOR)}

Untuk mengetahui pengaruh SIBOR terhadap spread suku bunga yang di himpun oleh bank umum di Indonesia akan dilakukan uji hipotesis secara individu. Dari hasil regresi diatas diketahui t-hitung : 4,307206 sedangkan signifikan yang digunakan adalah $\alpha: 5 \%$ df sehingga untuk pengujian dengan 2 arah dengan signifikan $0.025 \%$ data df : n-k-1(60-4-1) maka nilai t-tabel yang didapatkan $0,025 \%(55): \pm 2,00404$. Secara parsial SIBOR mepunyai pengaruh positif terhadap spread suku bunga yang dihimpun oleh Bank Umum Di Indonesia.

\section{2) Uji F}

Uji F dilakukan untuk mengetahui pengaruh variabel independent terhadap variabel dependent secara serentak atau bersama-sama.

F-hitung (33.36827) > F-tabel $(2,54)$ sehingga terletak di daerah penolakan $\mathrm{H}_{0}$ artinya BI Rate, ROA (return on asset), NPL (non 
performing loan) dan SIBOR (Singapore interbank offering rate) secara serentak dapat mempengaruhi spread suku bunga.

\section{3) Koefisien Determinasi $\left(\mathbf{R}^{2}\right)$}

Koefisien determinasi $\left(\mathrm{R}^{2}\right)$ dari model diatas adalah 0,708181 atau $70,82 \%$ hal ini menunjukkan bahwa variabel independent yang terdiri dari BI Rate, ROA (return on asset), NPL (non performing loan) dan SIBOR (Singapore interbank offering rate) dalam menjelaskan perubahan variabel dependent spread suku bunga sebesar 70,82 \% sedangkan sisanya sebesar $0,29 \%$ dijelaskan oleh variabel lain yang tidak dimasukkan dalam model estimasi.

\section{a. Uji Asumsi Klasik}

Pengujian asumsi klasik ini dilakukan untuk mengetahui ada tidaknya pelanggaran asumsi klasik sebagai syarat untuk dapat digunakannya pengujian hipotesis diatas pengujian asumsi kalsik ini terdiri dari uji autokorelasi, Multikorelineritas, Heterokesdasitas Dan Normalitas.

\section{1) Autokorelasi}

Untuk mengetahui terjadinya korelasi serial antar variabel independent (autokorelasi) maka salah satu uji yang dapat dilakukan adalah melalui uji durbin Watson yang tersedia dalam program eviews. DW terletak diantara du dan 4-du yaitu $(1,73)<$ DW $(2,110398)<4-d u(2,27)$ sehingga dapat disimpulkan bahwa model regresi diatas tidak terjadi korelasi serial antara kesalahan pengganggu atau $\mathrm{p}=0$

\section{2) Heterokedastisitas}

Pengujian heteroskedatisitas bertujuan untuk mengetahui apakah variasi residual absolut sama atau tidak sama untuk semua pengamatan. Berdasarkan uji White ada 2 yaitu yang pertama no croos terms di ketahui nilai Obs*R-square sebesar 42.21607 maka dengan nilai df $\mathrm{X}^{2}-$ hitung sebesar 68.60 sedangkan cross terms nilai Obs*R-square sebesar 46.42309 maka dengan nilai df $\mathrm{X}^{2}-$ hitung sebesar 61.63 maka dapat di simpulkan bahwa df $\mathrm{X}^{2}-$ hitung lebih besar dari pada Obs*R-square artinya tidak terjadi heteroskedastisitas.

\section{3) Multikolinearitas}

Pengujian multikolinearitas dilakukan untuk mengetahui ada tidaknya hubungan linear antara variabel independent satu dengan 
variabel independent lainnya. Pengujian multikolinearitas dilakukan melalui metode korelasi parsial. Pengujian ini terdiri atas beberapa langkah yaitu:

1. Melakukan regresi antara variabel dependent dengan variabel independent dihasilkan persamaan.

$$
\begin{aligned}
\mathrm{Y}= & 9.812189-0.290086(\mathrm{X} 1)- \\
& 1.077079(\mathrm{X} 2)+0.610417(\mathrm{X} 3)+ \\
& 1.127629(\mathrm{X} 4)
\end{aligned}
$$

Didapatkan R-squared 0.708181

\section{Regresi variabel independent}

a. BI Rate dengan ROA (return on asset), NPL (non performing loan) dan SIBOR (Singapore interbank offering rate) dalam bentuk $\left(\mathrm{R}^{2} 11\right)$, persamaan yang dihasilkan.

$$
\begin{aligned}
& X 1=6.036685-0.249642 \mathrm{X} 2+ \\
& 0.461477 \mathrm{X} 3-0.141137 \mathrm{X} 4
\end{aligned}
$$

Dari persamaan diatas dihasilkan R-squared sebesar 0.235749

b. ROA (return on asset) dengan BI Rte, NPL (non performing loan) dan SIBOR (Singapore interbank offering rate) dalam bentuk $\left(\mathrm{R}^{2} 12\right)$, persamaan yang dihasilkan.

$$
\begin{aligned}
& X 2=3.533346-0.026376 \mathrm{X} 1- \\
& 0.200693 \mathrm{X} 3+0.231607 \mathrm{X} 4
\end{aligned}
$$

Dari persamaan diatas dihasilkan R-squared sebesar 0.353983

c. NPL (non performing loan) dengan BI Rte, ROA (return on asset) dan SIBOR (Singapore interbank offering rate) dalam bentuk $\left(\mathrm{R}^{2} 13\right)$, persamaan yang dihasilkan.

$\mathrm{X} 3=4.331063+0.299964 \mathrm{X} 1-$ $1.234696 \mathrm{X} 2+0.311588 \times 4$

Dari persamaan diatas dihasilkan R-squared sebesar 0.419275

d. SIBOR (Singapore interbank offering rate) dengan BI Rate, ROA (return on asset), dan NPL (non performing loan) dalam bentuk $\left(\mathrm{R}^{2} 14\right)$, persamaan yang dihasilkan.

$$
\begin{aligned}
& \mathrm{X} 4=0.245801-0.012316 \mathrm{X} 1+ \\
& 0.191286 \mathrm{X} 2+0.041830 \mathrm{X} 3
\end{aligned}
$$

Dari persamaan diatas dihasilkan Rsquared sebesar 0.048168 .

Dari hasil regresi diatas diketahui bahwa $\mathrm{R}^{2} 1$ (0.708181) > $\mathrm{R}^{2} 11$ (0.235749), $\mathrm{R}^{2} 12$ (0.353983), $\mathrm{R}^{2} 13$ (0.419275), $\mathrm{R}^{2} 14$ (0.048168) sehingga dapat di simpulkan bahwa dalam model regresi diatas tidak terjadi multikolinearita

Berdasarkan hasil regresi dari keempat variabel bebas atau Independent yang terdiri dari BI 
Rate, ROA (return on asset), NPL (non performing loan) dan SIBOR (Singapore interbank offering rate) berpengaruh dan signifikan pada masing-masing regresi, lebih dijelaskan pengaruh variabel independent terhadap variabel dependent dapat diuraikan sebagi berikut :

\section{a. BI Rate Berpengaruh Negatif} dan Signifikan Terhadap Spread Suku Bunga

Pengaruh yang berbeda pula yang ditunjukkan oleh variabel suku bunga BI Rate, dimana suku bunga BI Rate mempunyai pengaruh negatif terhadap variabel dependent yaitu spread suku bunga. Hal ini berarti dapat dijelaskan bahwa penetapan spread suku bunga oleh bank secara signifikan mengikuti perubahan BI Rate, khususnya pada saat terjadinya penurunan BI Rate.

\section{Penurunan/kenaikan tingkat} suku bunga deposito akan direspon secara positif oleh pergerakan tingkat suku bunga pinjaman perbankan di Indonesia. Maka kenaikan BI Rate lebih kecil dari pada spread suku mengalami penurunan suku bunga pinjaman oleh perbankan maka perbankan dengan adanya perilaku tersebut adalah keinginan bank untuk menjaga margin antara biaya dana (cost of fund) dari suku bunga deposito dengan pendapatannya yaitu suku bunga pinjaman.

b. ROA (Return On Asset) Berpengaruh Negatif dan Signifikan Terhadap Spread Suku Bunga

Pengaruh yang berbeda pula yang ditunjukkan oleh variabel return on asset (ROA), dimana return on asset (ROA) mempunyai pengaruh negatif terhadap variabel dependent yaitu spread suku bunga. Hal ini menunjukkan bahwa adanya kenaikan spread suku bunga akan mengakibatkan adanya penurunan ROA. Karena bank Indonesia, sebagai pembina dan pengawas perbankan, lebih mengutamakan nilai profitabilitas suatu bank yang diukur dengan asset yang dananya sebagai berasal dari dana simpanan masyarakat, semakin besar ROA suatu bank, semakin besar pula tingkat keuntungan yang dicapai bank dan semakin baik posisi bank tersbut dari segi penggunaan asset. 
c. NPL (Non Performing Loan) Berpengaruh Positif dan Signifikan Terhadap Spread Suku Bunga

Pengaruh yang berbeda pula yang ditunjukkan oleh variabel non performing loan (NPL), dimana non oerforming loan (NPL) mempunyai pengaruh positif terhadap variabel dependent yaitu spread suku bunga. Hal ini menunjukkan pinjaman bermasalah terhadap spread suku bunga, dapat di lihat dari hasil hipotesis yang digunakan bahwa peningkatan pinjaman bermasalah berpengaruh terhadap peningkatan spread suku bunga hal ini beralasan karena meningkat pinjaman bermasalah akan meningkatkan resiko yang di hadapi oleh bank, sehingga berakibat pada peningkatan suku bunga kredit dan berdampak pada peningkatan spread suku bunga.

d. SIBOR (Singapore interbank offering rate) berpengaruh positif dan signifikan terhadap spread suku bunga

Pengaruh yang berbeda pula yang ditunjukkan oleh variabel Singapore interbank offering rate
(SIBOR), dimana Singapore interbank offering rate (SIBOR) mempunyai pengaruh positif terhadap variabel dependent yaitu spread suku bunga. Untuk menjaga keseimbangan valas dan mengantisipasi rupiah yang lebih lanjut, sehingga suku bunga deposit dan suku bunga kredit turut dinaikkan untuk menghindari spread yang dimana para investor akan menyimpan danaya di luar negeri karna nilai dollar lebih tinggi dari pada rupiah untuk mencegah aliran modal keluar maka tingkat suku bunga simpanan dinaikkan dan menyebabkan naiknya tingkat suku bunga pinjaman di inodesia.

\section{PENUTUP}

Penelitian ini dilakukan untuk melihat tentang analisi terhadap determinan spread suku bunga bank umum di Indonesia, dengan periode 2009-2013. Variabel yang digunakan dalam penilitian ini dilihat dari sektor internal yaitu return on asset (ROA) dan non performing loan (NPL) sedangkan yang eksternal yang digunakan antara lain BI Rate dan Singapore interbank offering 
rate (SIBOR). Berdasarkan hasil analisis data dan pembahasan maka dapat diambil kesimpulan sebagai berikut:

Berdasarkan hasil regresi berganda maka dapat disimpulkan bahwa BI Rate berpengaruh negatif dan signifikan terhadap spread suku bunga bank umum di Indonesia dengan koefisien $-3,750980$, artinya apabila BI Rate sebesar 1\% maka elastisitas spread suku bunga akan menurun sebesar -3.750 .

Return on asset (ROA) berpengaruh negatif dan signifikan terhadap spread suku bunga bank umum di Indonesia dengan koefisien regresi -4,527006, artinya apabila return on asset (ROA) sebesar 1\% maka spread suku bunga akan menurun sebesar $-4,527$.

Non performing loan (NPL) berpengaruh positif dan signifikan terhadap spread suku bunga bank umum di Indonesia dengan koefisien 6.363608, artinya apabila Non performing loan (NPL) naik $1 \%$ maka elastisitas spread suku bunga akan naik sebesar 6.363.

Singapore interbank offering rate (SIBOR) berpengaruh positif dan signifikan terhadap spread suku bunga bank umum di Indonesia dengan koefisien 4.307206, artinya apabila Singapore interbank offering rate (SIBOR) naik $1 \%$ maka elastisitas spread suku bunga akan naik sebesar 4.307.

\section{DAFTAR PUSTAKA}

Afzal, Ayesha \& Mirza, Nawazish. 2012. Interest Rate Spread In An Emergerning Economy: The Case Pakistan Commercial Bangking Sector, Economic Researh Vol 25 2014, (Hal 987-1004).

Ariyanto, taufik. 2011. Faktor penentu net interest margin perbankan Indonesia. Komisi pengawas persingan usaha.

Bank Indonesia. 2012. Statistik Ekonomi dan Keuangan Indonesia.

http://www.bi.go.id/web/id/Sta tistik/Statistik+Ekonomi+dan+ Keuangan+Indonesia/Versi+H

TM L/Sektor+Moneter/ diakses tanggal 18 November 2014.

Bank Indonesia. 2012. Laporan Perekonomian Indonesia. http://www.bi.go.id/web/id/Pu blikasi/Laporan+Tahunan/Lap 
oran+Perekonomian+Indonesi/

diakses tanggal 20 Desember 2014.

Dwijayanthy, Febrina dan Prima

Naomi (2009) Analisis

Pengaruh Inflasi, BI Rate, dan

Nilai Tukar Mata Uang

terhadap Profitabilitas Bank

Periode 2003-2007, Jurnal

Karisma, Vol3 (2)

Gujarati, Damodar, 2006, Dasar-

Dasar Ekonometrika, Edisi

ketiga, penerbit erlangga,

Jakarta

Ismail. 2011. Manajemen Perbankan;

Edisi Pertama, Cetak ke-2.

Kencana. Jakarta.

Judisseno, Rimsky K. 2005. System

Moneter Dan Perbankan

Indonesia. Jakarta : Gramedia

Pustaka Utama.

Kasmir. 2000. Bank Dan Lembaga

Keuangan Lainnya Edisi Baru.

PT RajaGrafindo. Jakarta.

Kasmir. 2011. Dasar-Dasar

Perbankan. Jakarta: Pt Raja

Grafindo Persada.

Khawaja, M Idress \& Din, Musleh-

Ud. 2007. Determinants of

Interest Spread in Pakistan,

The Pakistan Development

Review 46 : 2 (Summer 2007)
(Hlm 129-143). Pakistan:

Pakistan Development.

Kuncoro, Mudrajad. 2003. Metode

Riset Untuk Bisnis dan

Ekonomi. Erlangga. Jakarta.

Mujeri, Mustafa K\& Younus, Sayera. 2009. An Analysis of Interest Rate Spread in the Banking Sector in Bangladesh, The Bangladesh Development Studies Vol. XXXII, December 2009, No. 4. Bangladesh: Bangladesh Institute of Development Studies

Nasution, Darmin. 2012. Spread suku bunga harus turun. http://economy.okezone.com/re $\operatorname{ad} / 2012 / 05 / 24 / 457 / 634562 /$ redi rect diakses 23 november 2014. Sambodo, Maxensius Tri. 2001. Analisis Faktor - faktor yang mempengaruhi Suku Bunga Riil Kredit Investasi di Indonesia. Widyariset Vol. 2.

Siamat, Dahlan. 2005. Manajemen Lembaga Keuangan. Kebijakan moneter dan perbankan: Edisi kelima, Jakarta: lembaga penerbit fakulatas ekonomi Universitas Indonesia. 
Surat Edaran Bank Indonesia Nomor 12/11/DPNP tanggal 31 Maret 2010

surat edaran Bank Indonesian No.8/30/DPBPR/2006

Shofwan, Muhammad shodikin. 2013. "analisis variabelvariabel yang mempengaruhi spread suku bunga di Indonesia (studi kasus bank umum di Indonesia)'. Fakultas ekonomi dan bisnis universitas brawijaya malang.

Taswan. 2010. Manajemen Perbankan; Edisi kedua, penerbit UPP STIM YKPN. Yogyakarta.
Waljianah, Riza, el.al. (2013). "Determinan Tingkat Suku Bunga Pinjaman Perbankan Di Indonesia (periode juli 2005 desember 2011)'. Jurusan ilmu ekonomi fakultas ekonomi dan bisnis unversitas brawijaya malang.

Winarno, Wing Wahyu, 2007, Analisis Ekonometrika dan Statistika dengan Eviews, UPP STIM YKPN, Yogyakarta

Worldbank.2014.IndonesiaData.http: //.woldbank.org/indicator/NY. GDP.MKTP.KD.ZD/countries/ ID-4E-XN?display=graph (diakses 25 november 2014) 